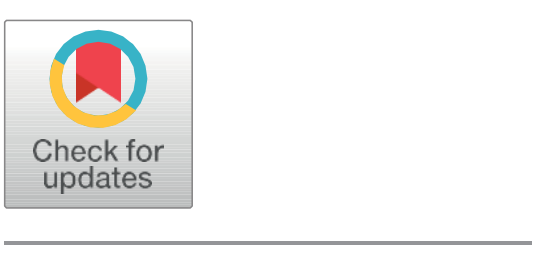

\section{Gopenaccess}

Citation: Ferreira, L. L., Carvalho, I. R., Conte, G. G., Amaral, G. C.L., Campos, J. N., Tomazele, A. A. S., Carrijo, N. S., Pereirra, V. T., Souza, A. T., \& Loro, M. V. (2022). Effect of biostimulant on yiel characters of common bean cultivars under Southwestern Goiás conditions Agronomy Science and Biotechnology, 8, 1-13

https://doi.org/10.33158/ASB.r148.v8. $\underline{2022}$

Received: September 25, 2021. Accepted: October 06, 2021.

Published: October 27, 2021.

English by: Francine Lautenchleger.

Copyright: () 2022 Agronomy Science and Biotechnology. This is an open access article distributed under the terms of the Creative Commons Attribution License, which permits unrestricted use, distribution, and reproduction in any medium, since the original author and source are credited.

RESEARCH ARTICLE

\title{
Effect of biostimulant on yield characters of common bean cultivars under Southwestern Goiás conditions
}

\author{
Luiz Leonardo Ferreira ${ }^{1}\left(\mathbb{D}\right.$, Ivan Ricardo Carvalho ${ }^{2, *}(\mathbb{D}$, Giordano Gelain \\ Conte $^{3}{ }^{(D}$, Gileade Costa Leonel Amaral ${ }^{1} \mathbb{D}$, Juliana Naves de Campos $^{1}(\mathbb{D}$, \\ Augusto Antonio de Souza Tomazele ${ }^{1}{ }^{(\mathbb{D}}$, Núbia de Sousa Carrijo ${ }^{1}{ }^{\mathbb{D}}$, Valúcia \\ Teodoro Pereira $^{1}$, Adriano Teixeira de Souza ${ }^{1} \mathbb{D}$ and Murilo Vieira Loro ${ }^{4} \mathbb{C}$

\begin{abstract}
${ }^{1}$ Universidade em Mineiros, Goiás, GO, Brazil. ${ }^{2}$ Regional University of the Northwest of the State of Rio Grande do Sul, Rua do Comércio, 3000, Universitário, ljuí, RS, Brazil, CEP 98700-000. ${ }^{3}$ Federal University of Pelotas, Department of Plant Science - Eliseu Maciel Avenue, no number, Capão do Leão, RS, Brazil, CEP 96160-000. ${ }^{4}$ Federal University of Santa Maria, Santa Maria, RS, Brazil. *Corresponding author, Email: carvalho.irc@gmail.com
\end{abstract}

\section{ABSTRACT}

This study aimed to evaluate the effect of biostimulant positioning on common bean cultivars in the southwestern Goiás conditions. The experiment was conducted in the municipality of Mineiros-GO. The experimental design was a randomized block in factorial $6 \times 3$, corresponding to the positioning of the Triplus biostimulator (R5, R5 + R8 and water) in six common bean cultivars (BRS Campeiro, BRS Esteio, BRS Estilo, BRS Marfim, BRS Notavel and BRS Perola) in 4 replicates. The following productive attributes were evaluated: number of pod, number total of grains, number of commercial grains, number of non-commercial grains, mass of commercial grains, thousand grains mass. There was a significant interaction between cultivar $\mathrm{x}$ biostimulant as well as the factors alone. At the end of the experiment, it was concluded that the positioning of the biostimulant via foliar in the R5 phenological phase provided the highest yields for all common bean cultivars, especially BRS Estilo (43.87 sc ha-1) and BRS Notavel (43.02 sc ha-1). Biostimulant applications at stage R5 promoted the best results for number of non-commercial grains, mass of commercial grains, thousand grains mass. In the three stratifications used in the dendrogram, it was possible to form two groups of genotypes. Number total of grains, number of commercial grains and number of pod positively correlate with yield.

Keywords: Phaseolus vulgaris L., growth regulator, secondary metabolism, plant regulators, seed treatment, resistance to biotic and abiotic factors. 


\section{INTRODUCTION}

In Brazil, common bean (Phaseolus vulgaris L.) is one of the main crops, because it is distributed all over national grounds presenting great adaptability to climatic diversity (Almeida, Soratto, Broetto, \& Cataneo, 2014; Coêlho, Gonçalves-Vidigal, Vidigal Filho, Franzon, \& Martins, 2020; Paulino et al, 2022). It represents an income and subsistence alternative for Brazilian farmers, due to the short cycle, low production cost, and sowing can occur during the normal and non-preferential season (Demari, Souza, Carvalho, Nardino, \& Follmann, 2015). It plays a major economic and social importance, as it is a protein source and a basic component of the diet (Silva, Fogaça, Moreira, Prado, \& Vasconcelos, 2016).

In order to increase the productivity of the common bean, new technologies have been developed and tested (Abrantes et al., 2011; Silva et al., 2016), mainly in order to reduce costs and increase the cultivation viability in regions with some sort of restriction, as hydric for instance (Bossolani et al., 2017). However, greater productivity can be achieved by the effective use of already consolidated technologies for the crop, such as the use of biostimulants (Ávila, Barizão, Gomes, Fedri, \& Albrecht, 2010).

Biostimulants can be defined as the mixture of one or more plant regulators with other compounds (amino acids, vitamins and nutrients). They are substances produced naturally by plants, but can also be synthesized (Santos et al., 2017). The biostimulant can be used both in seed treatment and in seeding lines and/or foliar sprays (Almeida et al., 2014; Abrantes et al., 2011).

When applied in small amounts, the biostimulant affects the growth of the plant and its development, as in the bean plant that plays an important role in the development, making the plant more resistant to environmental stresses (Santos et al., 2017). Researches on the use of biostimulants, associated or not to fertilization (Anjos at al., 2017), have been developed and the responses are quite contrasting, which opens up space for further research, in order to elucidate affirmative answers about the use of these substances in agriculture.

Abrantes et al. (2011), under Cerrado conditions, observed that the application of biostimulant increased the number of grains per plant and grain yield in common bean. Lana, Gozuen, Bonotto and Trevisan (2009) found increases in the production of bean grains with biostimulant, but the same did not influence the weight of a thousand grains and macro and micronutrient leaf contents. Silva et al. (2016), concluded that the biostimulant is more effective increasing the mass in vegetative phase and did not influenced bean yield components. Bossolani et al. (2017) verified that the effect of the combination of biostimulant and inducer of resistance to biotic and abiotic factors did not affect the components of bean production. Mambrin et al. (2020) verified that the supplementation in the bean crop promotes positive responses of dry mass of pods, grains, number of grains and grain yield.

However, the results found in the literature are still contradictory, varying according to the form and time of application, especially in common bean (Almeida et al., 2014). Silva et al. (2020), in a study with biostimulants in oats, showed that the positive effect of biostimulants is dependent on the conditions of the growing year, and that returns in productivity do not guarantee the viability of the application. In addition, few studies have investigated the effect of biostimulant on plants of different bean cultivars. In view of the above, the aim of this work was to evaluate and make the positioning of a biostimulant in common bean cultivars in southwestern of Goiás conditions. 


\section{MATERIAL AND METHODS}

The study was conducted between November 27, 2017 and March 28, 2018, at the Experimental Farm Luís Eduardo de Oliveira Salles, belonging to UNIFIMES, a rural area of the municipality of Mineiros, GO, Brazil. Geographically it is at latitude 170 58 'S and longitude 45 $22^{\prime} \mathrm{W}$ and with approximately $800 \mathrm{~m}$ of altitude. Mean temperature of $22.7^{\circ} \mathrm{C}$ and Mean annual precipitation of $1695 \mathrm{~mm}$, occurring mainly in spring and summer. The experimental area is classified as Aw climate (hot to dry) (Köppen \& Geiger, 1936).

The results of the chemical analysis of the soil samples in the $0-20 \mathrm{~cm}$ layer collected in the experiment area were: hydrogen potential 5.7; calcium 3, magnesium 0.8 , aluminum 0.2 , hydrogen + aluminum 2 , cation exchange capacity 5.9 , in $\mathrm{cmol}_{\mathrm{c}} \mathrm{dm}^{-3}$; potassium 53 , phosphorus 59 , sulfur 1.7 , boron 0.2 , copper 1.4, iron 51 , manganese 23 , zinc 8.3 , sodium 1.5 , in $\mathrm{mg} \mathrm{dm}^{-3}$; clay 223 , silt 50 , sand 728 , organic matter 20 and organic carbon 12 , in $\mathrm{g} \mathrm{dm}^{-3}$. The data were taken according to the methodology of (Empresa Brasileira de Pesquisa Agropecuária [EMBRAPA], 2009). The soil was classified as Typic Quartzipisamment of sandy texture (Empresa Brasileira de Pesquisa Agropecuária [EMBRAPA], 2013).

The experimental design was a randomized complete block design in $6 \times 3$ factorial, totaling 18 treatments. It was corresponding to the positioning of the biostimulant Triplus Anuais ${ }^{\circ}$ in the phenological phases ( R5, R5 + R8 and water) in 6 common bean cultivars (BRS Campeiro, BRS Esteio, BRS Estilo, BRS Marfim, BRS Notável and BRS Pérola), in 4 replicates, totaling 72 experimental units. Each unit was composed of 4 lines of 5 meters long spaced by $0.45 \mathrm{~m}$, the plot area was $9 \mathrm{~m}^{2}$, with a density of 12-13 seeds per meter of sowing line.

It was performed desiccation in pre-planting (Cobucci, Stefano, \& Kluthcouski 1999). The fertilization used was of $450 \mathrm{~kg} \mathrm{ha}^{-1}$ of the fertilizer $05-25-15$ applied in the sowing line and in a single dose next. The sowing was performed on November 29 , 2018. Triplus Anuais ${ }^{\circ}$ with its guarantees of phosphorus $2 \%$, boron $3.4 \%$, molybdenum $1 \%$ and nickel $0.35 \%$, was applied in the dose of $300 \mathrm{ml} \mathrm{ha}^{-1}$ per application. The phenological phases of application corresponded to R5: preflowering with appearance of the first buds and R8: grain filling (Oliveira et al., 2018).

The spraying was performed with knapsack sprayer used with constant pressure of 2.0 bar $\left(\mathrm{CO}_{2}\right)$, cone type, by applying a spray volume of $335 \mathrm{~L} \mathrm{~h}^{-1}$, in the warm hours of the day, with an Mean temperature environment of $25{ }^{\circ} \mathrm{C}$, relative humidity air above $60 \%$ and winds below $5 \mathrm{~km} \mathrm{~h}^{-1}$. During the course of the experiment, pest, disease and weed control were carried out as needed, respecting good practices and integrated management (Quintela, 2001).

At the end of each cycle, 10 plants of each cultivar were randomly collected on the utile area of the experimental plot. They were evaluated for the following agronomic attributes: NP number of pod (units plant ${ }^{-1}$ ); NGT number total of grains (units plant ${ }^{-1}$ ); NGC: number of commercial grains (unit plant ${ }^{-1}$ ); NGN: number of non-commercial grains (unit plant ${ }^{-1}$ ); PGC: mass of commercial grains (g plant ${ }^{-1}$ ); PMG: thousand grains mass (g); and REN: yield $\left(\mathrm{sc} \mathrm{ha}^{-1}\right)$. The plants of each cultivar were harvested and trashed in the phenological phase R9 according to Oliveira et al. 2018.

The data obtained were submitted to the assumptions of the statistical model, verifying the normality and homogeneity of the residual variances, as well as the additivity of the model. Afterwards, the analysis of variance was performed in order to identify the interaction between the bean cultivars $x$ positions of the biostimulant, when verifying significant interaction, they were submitted to the simple effects 
through the Scott-Knott Means clustering test, $5 \%$ probability. Afterward, the variables were submitted to a linear correlation in order to understand the association trend, and their significance was based on a $5 \%$ probability by the t-test. Subsequently, the genetic dissimilarity was determined by the Mahalanobis algorithm, where the residue matrix was weighted, the dendrogram of the distance was constructed through the UPGMA group, and the canonical biplot method was used, where it was possible to visualize the general variability of the experiment and the multivariate tendencies. The analysis were performed at the Rbio and $\mathrm{R}$ interface (Bhering, 2017).

\section{RESULTS AND DISCUSSION}

The summary of the analysis of variance with mean square (QM) and significance by the $\mathrm{F}$ test revealed a significant interaction between cultivar $\mathrm{x}$ biostimulant NGN, PGC, PMG and REN $(p<0.05)$. Significance was also observed in the cultivar factor in all variables $(p<0.01)$ and in the biostimulant factor for PGC and REN ( $p<0.05$ ) (Table 1). Corroborating with Abrantes et al. (2011), Bossolani et al. (2017), Anjos et al. (2017), Soratto, Souza-Schlick, Fernandes and Oliveira (2015) and Pavezi, Favarão and Korte (2017). However, Silva et al. (2016) and Santos et al. (2017), found no differences among the analyzed variables, with application of the biostimulant in the bean crop.

Table 1. Summary of variance analysis (calculated MS and CV (\%)) for NP: pod number; NGT: number of total grains; NGC: number of commercial grains; NGN: number of non-commercial grains; PGC: commercial grains mass; PMG: thousand grains mass and REN: yield, in common bean cultivars. Mineiros, GO, Brazil. UNIFIMES. 2019.

\begin{tabular}{ccccccccc}
\hline SV & DF & NP & NGT & NGC & NGN & PGC & PMG & REN \\
\hline Cx B & 10 & $6.76^{\mathrm{ns}}$ & $85.97^{\mathrm{ns}}$ & $64.26^{\mathrm{ns}}$ & $41.62^{*}$ & $4.39^{*}$ & $2882.30^{*}$ & $31.25^{*}$ \\
Cultivar (C) & 5 & $95.64^{* *}$ & $2142.58^{* *}$ & $1981.21^{* *}$ & $115.00^{* *}$ & $113.82^{* *}$ & $11708.71^{* *}$ & $809.53^{* *}$ \\
Biostimulant (B) & 2 & $18.89^{\mathrm{ns}}$ & $70.30^{\mathrm{ns}}$ & $114.15^{\mathrm{ns}}$ & $12.53^{\mathrm{ns}}$ & $5.76^{*}$ & $1316.00^{\mathrm{ns}}$ & $41.04^{*}$ \\
Block & 3 & $0.78^{\mathrm{ns}}$ & $43.73^{\mathrm{ns}}$ & $13.65^{\mathrm{ns}}$ & $95.75^{\mathrm{ns}}$ & $3.26^{\mathrm{ns}}$ & $412.27^{\mathrm{ns}}$ & $23: 22^{\mathrm{ns}}$ \\
Residue & - & 8.56 & 139.14 & 104.43 & 19.59 & 1.59 & 1167.66 & 11.34 \\
CV\% & - & 22.67 & 21.73 & 23.38 & 21.89 & 10.59 & 12.13 & 10.59 \\
\hline
\end{tabular}

${ }^{* *}$ significant at $1 \%$ probability by $\mathrm{F}$ test; ${ }^{*}$ significant at $5 \%$ probability by $\mathrm{F}$ test; ${ }^{\mathrm{ns}}$ not significant at $5 \%$ probability by the $\mathrm{F}$ test.

The NP was expressive for the cultivars BRS Estilo and BRS Notável in all biostimulant placements with Means of 15.72 - and 17.59 -units plant ${ }^{-1}$, as well for NGT values of 71.34 - and 69.58 -units plant ${ }^{-1}$, respectively (Table 2). Pavezi et al. (2017), also observed that common bean plants increased NP when performed seed treatment with biostimulant, same as found by Bertolin et al. (2010), in the soybean crop in leaves. However, Soratto et al. (2015), found no variation of NP with the application of growth regulator on bean. For Bossolani et al. (2017) the increase in the values obtained for NP may be related to the auxin present in the biostimulant. It participates in metabolic processes of growth, mainly by the cellular elongation, besides delaying the abscission of freshly fertilized flowers and pods in formation. It is a substance that plays an important role in the physiology of the plant.

The NGC was not influenced by the position of biostimulant, as stated by Ávila et al. (2010), where they did not observe variations in the means of this variable in leaf spraying of biostimulant. However, Abrantes et al. (2011), with the spraying of the growth regulator at the reproductive stage R5 increased the NGC per plant of 
bean cultivars. However, the cultivar factor differed, with the highest Means of cultivars BRS Campeiro, BRS Estilo and BRS Notável, with a mean of 55.56 units plant ${ }^{-1}$. NGC per plant is one of the most important yield components to achieve high levels of production, and decision making on the use of genetic materials adapted to environmental conditions becomes critical.

Table 2. Means for the NP number of total pods; NGT: number of grains in common bean cultivars. Mineiros, GO, Brazil. UNIFIMES. 2019.

\begin{tabular}{|c|c|c|c|c|c|c|}
\hline \multirow{3}{*}{ Cultivars } & \multicolumn{6}{|c|}{--------------- Positioning of the biostimulant in leaf ---------------- } \\
\hline & \multicolumn{3}{|c|}{ NP (unit plant ${ }^{-1}$ ) } & \multicolumn{3}{|c|}{ NGT (unit plant ${ }^{-1}$ ) } \\
\hline & R5 & $\mathrm{R} 5+\mathrm{R} 8$ & Water & R5 & R5 + R8 & Water \\
\hline BRS Campeiro & $15.83 \mathrm{aA}^{1}$ & $11.90 \mathrm{bA}$ & $12.50 \mathrm{aA}$ & $66.60 \mathrm{aA}$ & $53.33 \mathrm{aA}$ & $53.70 \mathrm{bA}$ \\
\hline BRS Esteio & $11.36 \mathrm{bA}$ & $12.73 \mathrm{bA}$ & $9.90 \mathrm{bA}$ & $56.60 \mathrm{aA}$ & 55.26 aA & $44.00 \mathrm{bA}$ \\
\hline BRS Estilo & $14.90 \mathrm{aA}$ & $16.63 \mathrm{aA}$ & $15.62 \mathrm{aA}$ & $68.16 \mathrm{aA}$ & $72.09 \mathrm{aA}$ & $73.76 \mathrm{aA}$ \\
\hline BRS Marfim & $11.86 \mathrm{bA}$ & $10.90 \mathrm{bA}$ & $6.36 \mathrm{bB}$ & $44.33 \mathrm{bA}$ & $49.06 \mathrm{aA}$ & $37.86 \mathrm{bA}$ \\
\hline BRS Notável & $17.10 \mathrm{aA}$ & $18.30 \mathrm{aA}$ & $17.36 \mathrm{aA}$ & $72.36 \mathrm{aA}$ & $65.03 \mathrm{aA}$ & $71.36 \mathrm{aA}$ \\
\hline BRS Pérola & $10.93 \mathrm{bA}$ & $9.43 \mathrm{bA}$ & $8.70 \mathrm{bA}$ & $30.13 \mathrm{bA}$ & $29.33 \mathrm{bA}$ & $33.93 \mathrm{bA}$ \\
\hline
\end{tabular}

${ }^{1}$ Means followed by the same lower case letter vertically (column) and upper case horizontally (row) do not differ by Scott-Knott's test at $5 \%$ probability.

The positioning of the biostimulant in $\mathrm{R} 5+\mathrm{R} 8$ reduced the NGN in the cultivars BRS Campeiro and BRS Estilo, where, for this last, in the positioning in R5 of the biostimulant, the reductions corresponded to $39.39,17.42$ and $66.57 \%$ when in comparison to the general Mean, respectively (Table 3). The data demonstrate that the use of biostimulant can increase the yield of the crop, either by improvement in grain filling, greater absorption of nutrients, or even resistance to biotic factors (insects and pathogens) and abiotic factors. As reported by Oliveira et al. (2015), with the use of biostimulant proportioned an increase in the production of cowpea beans in saline environment; and by Bertolin et al. (2010), when reporting that the positioning of biostimulant in vegetative and reproductive phase influenced the NP and REN of grains in the soybean crop.

Table 3. Means for NGC: commercial grain number and NGN: number of non-commercial grains of common bean cultivars. Mineiros, GO, Brazil. UNIFIMES. 2019.

\begin{tabular}{|c|c|c|c|c|c|c|}
\hline \multirow{3}{*}{ Cultivars } & \multicolumn{6}{|c|}{---------------- Positioning of the biostimulant in leaf ---------------- } \\
\hline & \multicolumn{3}{|c|}{ NGC (unit plant ${ }^{-1}$ ) } & \multicolumn{3}{|c|}{ NGN (plant- ${ }^{1}$ unit) } \\
\hline & R5 & $\mathrm{R} 5+\mathrm{R} 8$ & Water & R5 & $\mathrm{R} 5+\mathrm{R} 8$ & Water \\
\hline BRS Campeiro & $52.30 \mathrm{aA}^{1}$ & $46.93 \mathrm{aA}$ & $47.63 \mathrm{aA}$ & $14.30 \mathrm{aA}$ & $6.40 \mathrm{bB}$ & $6.06 \mathrm{bB}$ \\
\hline BRS Esteio & $50.03 \mathrm{aA}$ & $41.93 \mathrm{bA}$ & $34.60 \mathrm{bA}$ & $6.56 \mathrm{bA}$ & $13.33 \mathrm{aA}$ & $9.40 \mathrm{bA}$ \\
\hline BRS Estilo & $64.63 \mathrm{aA}$ & $63.36 \mathrm{aA}$ & $59.50 \mathrm{aA}$ & $3.53 \mathrm{bB}$ & $8.72 \mathrm{bB}$ & $14.26 \mathrm{aA}$ \\
\hline BRS Marfim & $28.53 \mathrm{bA}$ & $35.20 \mathrm{bA}$ & $21.33 \mathrm{bA}$ & $15.80 \mathrm{aA}$ & $13.86 \mathrm{aA}$ & $16.53 \mathrm{aA}$ \\
\hline BRS Notável & $58.53 \mathrm{aA}$ & $51.40 \mathrm{aA}$ & $55.76 \mathrm{aA}$ & $13.83 \mathrm{aA}$ & $13.63 \mathrm{aA}$ & $15.60 \mathrm{aA}$ \\
\hline BRS Pérola & $21.60 \mathrm{bA}$ & $26.43 \mathrm{bA}$ & $27.03 \mathrm{bA}$ & $8.53 \mathrm{bA}$ & $2.90 \mathrm{bA}$ & $6.90 \mathrm{bA}$ \\
\hline
\end{tabular}

${ }^{1}$ Means followed by the same lower case letter vertically (column) and upper case horizontally (row) do not differ by Scott-Knott's test at $5 \%$ probability.

The cultivar BRS Esteio elevated PGC in the presence of the biostimulant in both R5 and R5 + R8, as well as in BRS Notável, in R5. BRS Estilo presented higher mean in the different positions of the biostimulant and among the cultivars (Table 3). 
According to Lana et al. (2009), application of growth regulators in the first stages of the plant stimulates root growth, providing rapid recovering after drought stress period; greater resistance to insects, pests, diseases and nematodes; faster and uniform establishment of plants by increasing the uptake of nutrients and, consequently, crop yield.

The PMG was higher in the BRS Pérola cultivar and did not oscillate in the three positions of the biostimulant; however, the cultivar BRS Marfim had reduced PMG in the positioning of the biostimulant in R5 and R5 + R8 (Table 4). The increase of PMG with the use of growth regulator in common bean was also observed by Soratto et al. (2015) and Pedó et al. (2018). However, Abrantes et al. (2011), Pavezi et al. (2017), Lana et al. (2009) and Bossolani et al. (2017) did not observed variations in the PMG after the use of the biostimulant in common beans. According to Amaro et al. (2015), PMG is a measure used for different purposes, among them the comparison of the quality of seed lots in several species.

Table 4. Means for commercial grain weight PGC and weight of thousand grain PMG of bean cultivars. Mineiros, GO, Brazil. UNIFIMES. 2019.

\begin{tabular}{|c|c|c|c|c|c|c|}
\hline \multirow{3}{*}{ Cultivars } & \multicolumn{6}{|c|}{--------------- Positioning of the biostimulant in leaf---------------- } \\
\hline & \multicolumn{3}{|c|}{ PGC (g plant $^{-1}$ ) } & \multicolumn{3}{|c|}{ PMG (g) } \\
\hline & R5 & $\mathrm{R} 5+\mathrm{R} 8$ & Water & R5 & $\mathrm{R} 5+\mathrm{R} 8$ & Water \\
\hline BRS Campeiro & $11.60 \mathrm{bA}^{1}$ & $12.33 \mathrm{cA}$ & $11.20 \mathrm{bA}$ & $243.39 \mathrm{bA}$ & $262.28 \mathrm{aA}$ & $247.87 \mathrm{aA}$ \\
\hline BRS Esteio & $11.90 \mathrm{bA}$ & $10.50 \mathrm{cA}$ & $8.06 \mathrm{cB}$ & $238.00 \mathrm{bA}$ & $252.73 \mathrm{aA}$ & $233.20 \mathrm{aA}$ \\
\hline BRS Estilo & $16.45 \mathrm{aA}$ & $18.93 \mathrm{aA}$ & $17.35 \mathrm{aA}$ & $258.68 \mathrm{bA}$ & 299.13 aA & 293.26 aA \\
\hline BRS Marfim & $10.35 \mathrm{bA}$ & $9.60 \mathrm{da}$ & $8.33 \mathrm{cA}$ & $295.02 \mathrm{aB}$ & $272.81 \mathrm{aB}$ & $391.46 \mathrm{aA}$ \\
\hline BRS Notável & $16.13 \mathrm{aA}$ & $14.00 \mathrm{bB}$ & $13.66 \mathrm{bB}$ & $275.36 \mathrm{bA}$ & $272.44 \mathrm{aA}$ & $249.13 \mathrm{aA}$ \\
\hline BRS Pérola & $7.33 \mathrm{cA}$ & $7.90 \mathrm{da}$ & $9.03 \mathrm{cA}$ & $345.01 \mathrm{aA}$ & $307.31 \mathrm{aA}$ & $334.48 \mathrm{aA}$ \\
\hline
\end{tabular}

${ }^{1}$ Means followed by the same lower case letter (column) and upper case horizontal (row) do not differ by Scott-Knott's test at 5\% probability.

Positioning in R5 + R8 reduced the REN in the cultivar BRS Notável. BRS Estilo was, among the cultivars, the highest REN for all the biostimulant positions in R5: $43.87 \mathrm{sc} \mathrm{ha}^{-1}$, R5 + R8: $50.48 \mathrm{sc} \mathrm{ha}^{-1}$ and Water: $46.26 \mathrm{sc} \mathrm{ha}^{-1}$ (Table 5). Corroborating with Abrantes et al. (2011), with the application of growth regulator the REN increased in common bean cultivars. Bossolani at al. (2017), reached $62.60 \mathrm{sc} \mathrm{ha}^{-1}$ of REN when associated with the highest efficiency dose, corresponding to an increase of $9.76 \%$. It helped to consolidate what Nardi, Pizzeghello, Schiavon and Ertani (2016), commented, that recent studies support the potential of different types of biostimulants to improve plant biomass, crop yield and resistance to multiple types of stress.

Table 5. Means for REN of common bean cultivars. Mineiros, GO, Brazil. UNIFIMES. 2019.

\begin{tabular}{|c|c|c|c|}
\hline \multirow{3}{*}{ Cultivars } & \multicolumn{3}{|c|}{$\operatorname{REN}\left(\mathrm{sc} \mathrm{ha}^{-1}\right.$ ) } \\
\hline & \multicolumn{3}{|c|}{ 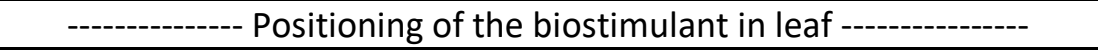 } \\
\hline & R5 & $\mathrm{R} 5+\mathrm{R} 8$ & Water \\
\hline BRS Campeiro & $30.93 \mathrm{bA}^{1}$ & $32.88 \mathrm{cA}$ & $29.86 \mathrm{cA}$ \\
\hline BRS Esteio & $31.73 \mathrm{bA}$ & $28.00 \mathrm{cA}$ & $21.51 \mathrm{~dB}$ \\
\hline BRS Estilo & 43.87 aA & $50.48 \mathrm{aA}$ & $46.26 \mathrm{aA}$ \\
\hline BRS Marfim & $27.60 \mathrm{bA}$ & $25.60 \mathrm{da}$ & $22.22 \mathrm{da}$ \\
\hline BRS Notável & $43.02 \mathrm{aA}$ & $37.33 \mathrm{bB}$ & $36.44 \mathrm{bB}$ \\
\hline BRS Pérola & $19.55 \mathrm{cA}$ & $21.06 \mathrm{da}$ & $24.08 \mathrm{da}$ \\
\hline
\end{tabular}

${ }^{1}$ Means followed by the same lowercase vertical letter do not differ by Scott-Knott test at $5 \%$ probability. 
According to Bertolin et al. (2010), the biostimulant allowed an increase in NP and REN in both in seed application and foliar application. Lana et al. (2009), observed that the spraying of biostimulant provided productivity indexes superior to those of the control (absence of phytoregulators), which had the lowest bean productivity index. Almeida et al. (2014) evaluated the effect of forms and times of application of biostimulant. They verified that the application of biostimulant via foliar in the vegetative phase, or beginning of the reproductive stage, proportioned an increase in nodulation, root growth, soluble sugars content and total amino acids and in nitrate reductase activity, however, did not interfere with shoot growth and REN of common bean crop.

Understanding the linear correlation between characters is essential to obtain efficient responses that can be used in indirect selection to enhance some trait (Nardino et al., 2016). The simple correlation matrix revealed a positive correlation in bean characteristics in the REN $\times$ NGT and REN $\times$ NGC pairs in all the biostimulant positions, as well as, the NGT x NP and NGT x NGT (Table 6). Montanari et al. (2013), also observed significant correlations between bean yield components. The magnitude of the correlation coefficients ranged from -0.0077 to 0.97578 (Table 6). Velho et al. (2017), estimated correlation coefficients of -0.04 to 0.72 in components of the shoot of the bean.

Table 6. Simple matrix of phenotypic correlation of common bean cultivars submitted to biostimulant placements in leaf. Mineiros, GO, Brazil. UNIFIMES. 2019.

\begin{tabular}{|c|c|c|c|c|c|c|}
\hline \multirow{2}{*}{ Variables } & $N P^{1}$ & NGT & NGC & NGN & PMG & REN \\
\hline & \multicolumn{6}{|c|}{ Water } \\
\hline NP & 1 & & & & & \\
\hline NGT & $0.95162^{* *}$ & 1 & & & & \\
\hline NGC & $0.969^{* *}$ & $0.96377^{* *}$ & 1 & & & \\
\hline NGNC & $0.21311^{\mathrm{ns}}$ & $0.41022^{\mathrm{ns}}$ & $0.1521^{\mathrm{ns}}$ & 1 & & \\
\hline PMG & $-0.6359^{n s}$ & $-0.4937^{\mathrm{ns}}$ & $-0.638^{n s}$ & $0.35174^{\mathrm{ns}}$ & 1 & \\
\hline REND & $0.852^{*}$ & $0.92371^{* *}$ & $0.8986^{*}$ & $0.35036^{\mathrm{ns}}$ & $-0.2589^{n s}$ & 1 \\
\hline \multicolumn{7}{|c|}{ Biostimulant positioned in the phenological phase R5 } \\
\hline NP & 1 & & & & & \\
\hline NGT & $0.86689^{*}$ & 1 & & & & \\
\hline NGC & $0.7565^{\mathrm{ns}}$ & $0.95753^{* *}$ & 1 & & & \\
\hline NGNC & $0.24827^{\mathrm{ns}}$ & $-0.0077^{\mathrm{ns}}$ & $-0.2957^{\mathrm{ns}}$ & 1 & & \\
\hline PMG & $-0.4513^{\mathrm{ns}}$ & $-0.6055^{\mathrm{ns}}$ & $-0.7201^{n s}$ & $0.49118^{\mathrm{ns}}$ & 1 & \\
\hline REND & $0.76361^{\mathrm{ns}}$ & $0.90021^{*}$ & $0.91956^{* *}$ & $-0.2069^{\mathrm{ns}}$ & $-0.4553^{\mathrm{ns}}$ & 1 \\
\hline \multicolumn{7}{|c|}{ Biostimulant positioned in phenological phase $\mathrm{R} 5+\mathrm{R} 8$} \\
\hline NP & 1 & & & & & \\
\hline NGT & $0.88065^{*}$ & 1 & & & & \\
\hline NGC & $0.84797^{*}$ & $0.9541^{* *}$ & 1 & & & \\
\hline NGNC & $0.44934^{\mathrm{ns}}$ & $0.53493^{\mathrm{ns}}$ & $0.25734^{\mathrm{ns}}$ & 1 & & \\
\hline PMG & $-0.0605^{n s}$ & $-0.2552^{\mathrm{ns}}$ & $-0.0695^{n s}$ & $-0.6269^{n s}$ & 1 & \\
\hline REND & $0.81781^{*}$ & $0.89561^{*}$ & $0.97578^{* *}$ & $0.137^{\mathrm{ns}}$ & $0.14583^{\mathrm{ns}}$ & 1 \\
\hline
\end{tabular}

${ }^{1} \mathrm{NP}$ : number of pods; NGT: total grain number; NGC: number of commercial grains; NGN: number of non-commercial grains; PGC: commercial grain mass; PMG: thousand grain mass and REN: yield. Significance: ${ }^{*} 5 \%$ probability; ${ }^{* *} 1 \%$ probability; ${ }^{\text {ns }}$ not significant.

From a total of 45 phenotype correlations, only $35.56 \%$ were significant by the $t$ test, regardless of the level of significance ( $p<0.01$ or $p<0.05$ ), according to the classification proposed by (Shimakura \& Ribeiro Junior, 2012). In stratified form, we 
can observe that in the positioning with water the significant correlations reached $40 \%$, followed by $26.67 \%$ and $40.00 \%$ for the R5 and R5 + R8 positions, respectively (Table 6). Gonçalves et al. (2017), analyzing 55 phenotypic correlations found only $36.36 \%$ of significance. Velho et al. (2017), state that the bean populations evaluated do not show a complete relationship between the characters, which indicates that the best strategy should be the simultaneous selection of characters, with emphasis on characters with and significant indirect effects.

The network correlation applied to the characteristics of the bean cultivars in different positions of the biostimulant indicated positive interconnection among the NP, NGT, NGC and REN variables (Table 6). Negative correlation was observed in PMG with NP and NGC (Table 6), PMG with NGC and PMG with NGN. The relative contribution of each character to the genetic divergence is of great importance to identify the characters of greatest contribution and also to help discard those that contribute little to the discrimination of the genotypes, reducing, in this way, labor, time and cost spent on experimentation (Correa \& Gonçalves, 2012). For Gonçalves et al. (2017), strong to moderate correlation coefficients are more important in the early selections of bean access, being used as a basis for the correct selection of these genotypes by indirect selection.

The first and second canonical variables respond with 95.3\% (Figure $1 \mathrm{~A}$ ), 95.8\% (Figure $1 \mathrm{~B}$ ) and $94.5 \%$ (Figure $1 \mathrm{C}$ ) of the total data variation, observing that the variables NGT, NP, NGC and REN presented similarities of magnitude between themselves, in the different positions of the biostimulant, whereas the PMG did not present proximities with these (Figure 1).

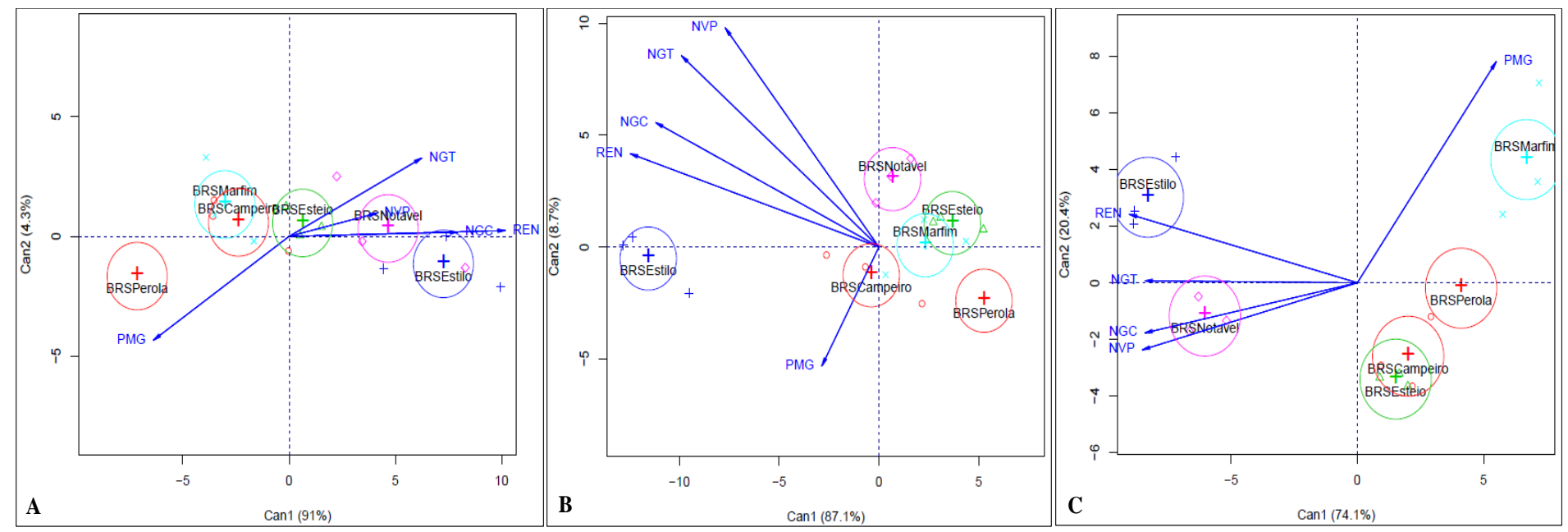

Figure 1. Analysis of canonical variables of the means of NP: pod number; NGT: total grain number; NGC: number of commercial grains; NGN: number of non-commercial grains; PMG: thousand grain weight; and REN: yield, in common bean cultivars subjected to foliar biostimulant placement on phenological phase R5 (A) R5 + R8 (B) and water (C). Mineiros, GO, Brazil. UNIFIMES. 2019.

Correa and Gonçalves (2012) observed that the first two canonical variables explain more than $80 \%$ of the total variation contained in the original data set $(97.94$ $\%$ of the total cumulative variance). Thus, the first two canonical variables explain the variability manifested among the analyzed cultivars, allowing to interpret the phenomenon, with considerable simplification, by means of a bi-dimensional scatter plot of the obtained scores.

There is influence of the cultivar BRS Pérola in the PMG and BRS Remarkable and BRS Estilo for the other variables (Figure 1A). In the positioning of the biostimulant, in R5 little influence of the cultivars on the variables was observed (Figure 1). The BRS 
Notável, with expressivity for the NGT, NGC, and NP, as well as the design BRS Estilo in REN and PMG for BRS Marfim, were the measurable observations in the positioning of the biostimulant in R5 + R8 (Figure 1C). Silva et al. (2015) state that multivariate analysis techniques are efficient to verify the similarities or differences in productivity variability, based on the chemical and physical attributes of the soil in the studied area.

Through the dendrogram, the bean cultivars were grouped into two distinct clusters for each biostimulant positioning. This allows us to quantify the similarity and dissimilarity between genotypes, the distinction between groups and how these groups can be contrasted in their characteristics (Meira et al., 2016). Isolated cluster formation was observed in the BRS Marfim (Figure 2A) and BRS Pérola (Figure 2B) in the biostimulant positions in R5 and R5 + R2, respectively. BRS Marfim and BRS Pérola formed Cluster in the positioning of the biostimulant with water (Figure $2 \mathrm{C}$ ). The results corroborate with Correa and Gonçalves (2012), when concluding that the techniques of multivariate analysis used gathered the genotypes in distinct groups, as well as in Silva et al. (2015), which through the dendrogram technique obtained by the analysis of hierarchical groupings also obtained the division of the cultivars into groups.

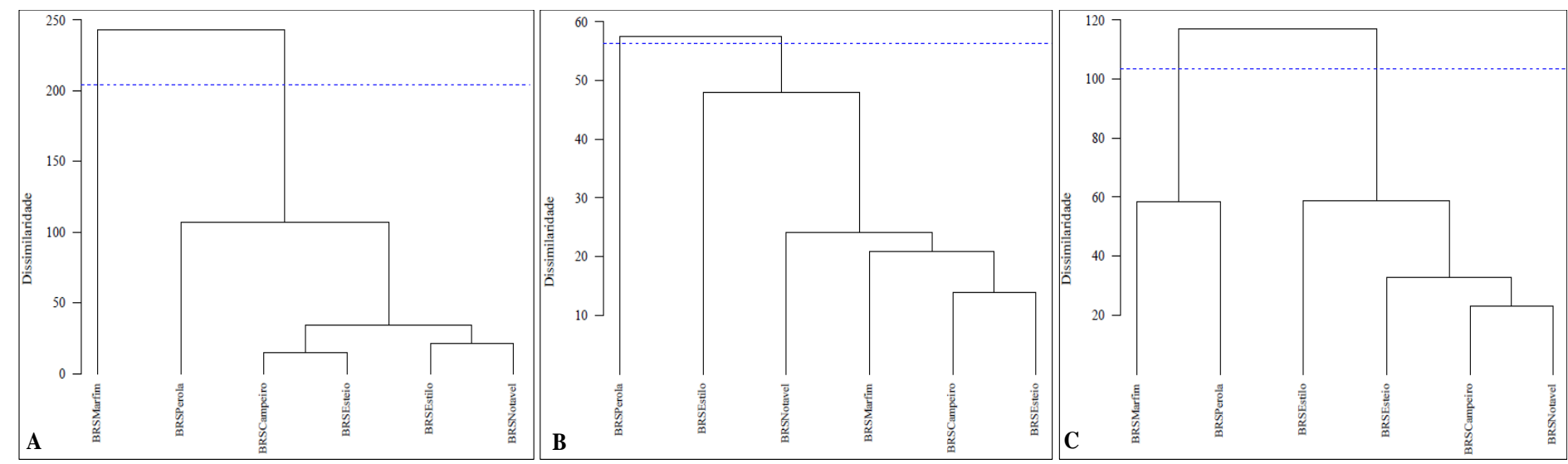

Figure 2. Dendrogram representative of dissimilarity between bean cultivars submitted to biostimulant placements in leaves in phenological stage R5 (A), R5 + R8 (B) and Water (C), obtained by the nearest neighbor technique, based on Euclidean distance. The variables of NP were taken: pod number; NGT: total grain number; NGC: number of commercial grains; NGN: number of non-commercial grains; PGC: commercial grain weight; PMG: thousand grain weight; and REN: yield. Mineiros, GO, Brazil. UNIFIMES. 2019.

\section{CONCLUSIONS}

The number of pods, number of non-commercial grains, mass of commercial grains, mass of a thousand grains and yield showed greater expression with application of biostimulant at stage R5.

The positioning of the biostimulant in leaf at phenological phase gave the highest yields for all common bean cultivars, especially BRS Estilo (43.87 sc ha-1) and BRS Notável (43.02 sc ha ${ }^{-1}$ ).

The common bean cultivars, regardless of the positioning of the biostimulant, were significantly positively correlated with the number of total grains and the number of commercial grains.

The variables number of pods, number of total grains, number of commercial grains and yield have a positive correlation.

BRS Estilo had little influence on performance components. 
The bean cultivars presented the formation of two distinct clusters according to the positions of the biostimulant.

\section{REFERENCES}

Abrantes, F., Sá, M., Souza, L. C., Silva, M., Simidu, H., Andreotti, M., Buzetti, S., Valério Filho, W., \& Arruda, N. (2011). Uso de regulador de crescimento em cultivares de feijoeiro de inverno. Pesquisa Agropecuária Tropical, 41(2), 148154. https://revistas.ufg.br/pat/article/view/8287

Almeida, A. Q. D., Soratto, R. P., Broetto, F., \& Cataneo, A. C. (2014). Nodulação, aspectos bioquímicos, crescimento e produtividade do feijoeiro em função da aplicação de bioestimulante. Semina: Ciências Agrárias, 35(1), 77-88. http://dx.doi.org/10.5433/1679-0359.2014v35n1p77

Amaro, H. T. R., David, A. M. S. S., Assis, M. O., Rodrigue, B. R. A., Cangussú, L. V. S., \& Oliveira, M. B. (2015). Testes de vigor para avaliação da qualidade fisiológica de sementes de feijoeiro. Revista de Ciências Agrárias, 38(3), 383-389.

Anjos, D. N., Mendes, H. T. A., Vasconcelos, R. C., Moreira, P. M., Cangussu, A. C. V., \& Pires, E. S. (2017). Índice de área foliar, spad e massa de matéria seca do feijoeiro comum em função dos bioestimulantes, NPK e micronutrientes em Vitória da Conquista-BA. Agrarian, 10(35), 1-9. https://doi.org/10.30612/agrarian.v10i35.4062

Ávila, M. R., Barizão, D. A. O., Gomes, E. P., Fedri, G., \& Albrecht, L. P. (2010). Cultivo de feijoeiro no outono/inverno associado à aplicação de bioestimulante e adubo foliar na presença e ausência de irrigação. Scientia Agraria, 11(3), 221-230. http://dx.doi.org/10.5380/rsa.v11i3.17230

Bertolin, D. C., Sá, M. E., Arf, O., Furlani Junior, E., Colombo, A. S., \& Carvalho, F. L. B. M. (2010). Aumento da produtividade de soja com a aplicação de bioestimulantes. Bragantia, 69(2), 339-347. http://dx.doi.org/10.1590/\$000687052010000200011.

Bhering, L. L. (2017). Rbio: A tool for biometric and statistical analysis using the $R$ platform. Crop Breeding and Applied Biotechnology, 17(2), 187-190. https://doi.org/10.1590/1984-70332017v17n2s29

Bossolani, J. W., Sá, M. E., Merloti, L. F., Víctor, J., Bettiol, T., Roberto, G., ... Pereira, S. (2017). Bioestimulante vegetal associado a indutor de resistência nos componentes da produção de feijoeiro. Revista Agro@mbiente On-Line, 11(4), 307-314. https://doi.org/http://dx.doi.org/10.18227/19828470ragro.v11i4.4094

Cobucci,T., Stefano, J. G., \& Kluthcouski, J. (1999). Manejo de plantas daninhas na cultura do feijoeiro em plantio direto. Circular Técnica, 35. Santo Antônio de Goiás, GO: Embrapa Arroz e Feijão. 
Coêlho, M., Gonçalves-Vidigal, M. C., Vidigal Filho, P. S., Franzon, R. C., \& Martins, V. S. R. (2020). Genetic diversity of Colletotrichum lindemuthianum races based on ITS-rDNA regions. Agronomy Science and Biotechnology, 6, 1-18. https://doi.org/10.33158/asb.r112.v6.2020

Correa, A. M., \& Gonçalves, M. C. (2012). Divergência genética em genótipos de feijão comum cultivados em Mato Grosso do Sul. Revista Ceres, 59(2), 206-212. http://dx.doi.org/10.1590/S0034-737X2012000200009

Demari, G. H., Souza, V., Carvalho, I. R., Nardino, M., \& Follmann, D. (2015). Feijão em época não preferencial submetido a doses de nitrogênio e seu impacto nos caracteres agronômicos. Enciclopédia Biosfera, 11(21), 1102-1112.

EMBRAPA - Empresa Brasileira de Pesquisa Agropecuária (2009). Manual de análises químicas de solos, plantas e fertilizantes. ( $2^{\mathrm{a}}$ ed.). Brasília, DF: Embrapa Solos.

EMBRAPA - Empresa Brasileira de Pesquisa Agropecuária (2013). Sistema Brasileiro de Classificação de Solos. (3 $3^{a}$ ed.). Revista e ampliada. Brasília, DF: Embrapa Solos.

Gonçalves, D. L., Barelli, M. A. A., Oliveira, T. C., Santos, P. R. J., Silva, C. R., Poletine, J. P., \& Neves, L. G. (2017). Genetic correlation and path analysis of common bean collected from Caceres Mato Grosso State, Brazil. Ciência Rural, 47(8), e20160815. http://dx.doi.org/10.1590/0103-8478cr20160815

Köppen, W., \& Geiger, R. (1936). Handbuch der klimatologie. Berlin: Gebrüder Borntraeger.

Lana, R. M. Q., Lana, A. M. Q., Gozuen, C. F., Bonotto, I., \& Trevisan, L. R. (2009). Aplicação de reguladores de crescimento na cultura do feijoeiro. Bioscience Journal, 25(1), 13-20. http://www.seer.ufu.br/index.php/biosciencejournal/article/view/6699

Mambrin, R. B., Sausen, D., Moura, D. S., Carvalho, I. R., Szareski, V. J., \& Lautenchleger, F. (2020). Selection of bean lineages regarding the use and response to phosphorus available in nutrient solution. Research, Society and Development, 9(11), 1-23. https://doi.org/10.33448/rsd-v9i11.8850

Meira, D., Carvalho, I. R., Nardino, M., Follmann, D. N., Pelegrin, A. J., Szareski, V. J., Ferrari, M., Olivoto, T., Meier, C., \& Souza, V. (2016). Path analysis and dissimilarity in soybean with in-determinate habit. International Journal of Current Research, 8(10), 39568-39573.

Montanari, R., Pellin, D. M. P., Silva Júnior, C. A., Carvalho, M. P., Gioia, M. T., \& Dalchiavon, F.C. (2013). Correlação entre produção de feijão e atributos físicos de um Latossolo em Mato Grosso do Sul. Revista Ceres, 60(6), 772-784. http://dx.doi.org/10.1590/S0034-737X2013000600005

Nardi, S., Pizzeghello, D., Schiavon, M., \& Ertani, A. (2016). Plant biostimulants: physiological responses induced by preotein hydrolyzed-based products and humic substances in plant metabolism. Scientia Agricola, 73(1), 18-23. http://dx.doi.org/10.1590/0103-9016-2015-0006 
Nardino, M., Baretta, D., Carvalho, I. R., Follmann, D., Konflanz, V. A., Souza, V. Q., Oliveira, A. C., \& Maia, L.C . (2016). Correlações fenotípica, genética e de ambiente entre caracteres de milho híbrido da Região Sul do Brasil. Revista Brasileira de Biometria, 34(3), 379-394.

Oliveira, F. A., Medeiros, J. F., Alves, R. C., Lima, L. A., Santos, S. T., \& Régis, L. R. (2015). Produção de feijoeiro caupi em função da salinidade e regulador de crescimento. Revista Brasileira de Engenharia Agrícola e Ambiental, 19(11), 1049-1056. http://dx.doi.org/10.1590/1807-1929/agriambi.v19n11p10491056

Oliveira, L. F. C., Oliveira, M. D. C., Wendland, A., Heinemann, A., Guimarães, C., Ferreira, E. D. B., \& Silveira, P. M. (2018). Conhecendo a fenologia do feijoeiro e seus aspectos fitotécnicos. Santo Antônio de Goiás, GO: Embrapa Arroz e Feijão.

Paulino, P. P. S., Gonçalves-Vidigal, M. C., Bisneta, M. V., Vidigal Filho, P. S., Nunes, M. P. B. A., Xavier, L. F. S., ... Lacanallo, G. F. (2022). Occurrence of anthracnose pathogen races and resistance genes in common bean across 30 years in Brazil. Agronomy Science and Biotechnology, 8, 1-21. https://doi.org/10.33158/asb.r140.v8.2022

Pavezi, A., Favarão, S. C. M., \& Korte, K. P. (2017). Efeito de diferentes bioestimulantes na cultura do feijoeiro-comum. Revista Campo Digital, 12(1), 30-35.

https://revista2.grupointegrado.br/revista/index.php/campodigital/article/vie w/1965

Pedó, T., Martinazzo, E. G., Bacarin, M. A., Antunes, I. F., Koch, F., Monteiro, M. A., \& Aumonde, T. Z. (2018). Crescimento de plantas e vigor de sementes de feijoeiro em resposta à aplicação exógena de ácido giberélico. Revista de Ciências Agrárias, 41(3), 181-190. http://dx.doi.org/10.19084/RCA17169

Quintela, E. D. (2001). Manejo integrado de pragas do feijoeiro. Circular técnica, 46. Santo Antônio do Goiáis, GO: Embrapa Arroz e Feijão.

Santos, J. P., Borges, T. S., Silva, N. T., Alcantra, E., Rezende, R. M., \& Freitas, A. S. (2017). Efeito de bioestimulante no desenvolvimento do feijoeiro. Revista da Universidade Vale do Rio Verde, 15(1), 815-824.

Shimakura, S. E., \& Ribeiro Júnior, P. J. (2012). Estatística descritiva: interpretação do coeficiente de correlação. Curitiba, PR: Departamento de Estatística da UFPR.

Silva, R., Fogaça, J. J. N. L., Moreira, E. S., Prado, T. R., \& Vasconcelos, R. C. (2016). Morfologia e produção de feijoeiro comum em função da aplicação de bioestimulante. Scientia Plena, 12(10), 1 10. http://dx.doi.org/10.14808/sci.plena.2016.100201

Silva, E. M. S., Montanari, R., Panosso, A. R., Correa, A. R., Tomaz, P. K., \& Ferraudo, A. S. (2015). Variabilidade de atributos físicos e químicos do solo e produção de feijoeiro cultivado em sistema de cultivo minimo com irrigação. Revista Brasileira de Ciência do Solo, 39, (2), 598607. http://dx.doi.org/10.1590/01000683rbcs20140429 
Silva, J. A. G., Mamann, A. T. W., Scremin, O. B., Carvalho, I. R., Pereira, L. M., Lima, A. R. C., Lautenchleger, F., Basso, N. C. F., Argenta, C. V., Berlezi, J. D., Porazzi, F. U., Matter, E. M., \& Norbert, L. (2020). Biostimulants in the indicators of yield and industrial and chemical quality of oat grains. Journal of Agricultural Studies, 8(2), 68-87. https://doi.org/10.5296/jas.v8i2.15728

Soratto, R. P., Souza-Schlick, G. D., Fernandes, A. M., \& Oliveira, L. F. F. A. (2015). Crescimento e produtividade de duas cultivares de feijoeiro em função de doses de ácido 2, 3, 5-triiodobenzoico. Ciência Rural, 45(12), 21812186. https://doi.org/10.1590/0103-8478cr20140389

Velho, L. P. S., Gemeli, M. S., Trevisani, N., Pereira, T. C. V., Cerutti, P. H., Melo, R. C., Guidolin, A. F., Coimbra, J. L. M., \& Corrêa, S. C. (2017). Phenotypic correlation and direct and indirect effects of aerial part components with root distribution of common bean. Pesquisa Agropecuária Brasileira, 52(5), 328-334. http://dx.doi.org/10.1590/s0100-204×2017000500006 